\title{
Review
}

\section{The Oxford handbook of global justice}

Thom Brooks (ed.)

Oxford University Press, Oxford, 2020, 560pp,

ISBN: 9780198714354

Contemporary Political Theory (2021) 20, S192-S197. https://doi.org/10.1057/s41296020-00461-x; published online 15 January 2021

The Oxford Handbook of Global Justice, edited by Thom Brooks, is an excellent compendium of global justice theory by leading figures, representing the state of the art in the field. What is less clear is how well the state of the art fares in its capacity to generate analytically and normatively useful theory and-presumably a related concern-also to engage with the empirics of global (in)justice. As well as surveying some of the many highlights, this review will raise some general empirical and theoretical issues with global justice theorization today.

The chapters cover a range of topics, some of which are well-mined seams of research, while others are, as Brooks writes, 'refreshing, innovative new ideas' (p. 1). The twenty-five chapters are grouped around seven themes: global egalitarianism and its critics, human rights, severe poverty, climate change justice, just global institutions, borders and territorial rights, and global injustice. Each consists of two to five chapters, not all of which I will address here.

There are many standout chapters in the handbook. Luis Cabrera's chapter on global citizenship, Brooks' chapter on climate change, Steven R. Ratner's chapter on international law, Christopher Heath Wellman's critique of territorial rights, and Simon Caney's chapter on the right to resistance will be go-to articles for scholars looking for respite from the usual global justice fare. A few chapters forego developing new arguments and instead survey the state of a particular line of investigation. These chapters are all also excellent. They include Alison M. Jagger's critique of feminism and global justice theory and practice, David Miller's survey of the cosmopolitanism/statism debate, János Kis' two-level account of distributive egalitarianism, Brooks' chapter on the capabilities approach, and Miriam Ronzoni and Laura Valentini's survey of the literature on statism and cosmopolitanism.

Krushil Watene's chapter on Māori political philosophy is one of the highlights of the volume. Writing against the mainstream western, Rawlsian, and capabilities approaches, Watene makes a good case that there are deep-seated, perhaps unshakable problems with the contemporary canon. That's the negative take away.

(C) 2021 The Author(s), under exclusive licence to Springer Nature Limited part of Springer Nature. 14708914 Contemporary Political Theory Vol. 20, S4, S192-S197 www.palgrave.com/journals 
The positive case for indigenous global justice theory-specifically a Kaupapa Māori theory_is a fascinating critique of justice, but not obviously a critique of global justice. The chapter is a breath of fresh air, and one comes away from it wondering about the world of other philosophical traditions-Indigenous and nonWestern-which could have been addressed in this handbook.

Arthur Chin's chapter engages in a nuanced critique of Thomas Pogge and some of his critics. It is a focused critique-perhaps too focused for a handbook. Nevertheless, it is an interesting de- and reconstruction of Pogge's critique, honed against potential criticisms. It also calls attention to a glaring absence from the handbook: Pogge's own contribution, or at least a contribution that is historically informed and focuses squarely on negative duties and the exploitative and violent nature of the international economic order.

Carol C. Gould's chapter is a rallying call for a more empathic politics grounded in what would have to be a global popular education in empathy. It is an original study of emotions and their relationship to political action. Much of Gould's argument is inspired by Iris Marion Young's work, specifically Young's theory of social connectivity and its relation to responsibility to resist injustice. Gould's core concern is that Young's theory ends up in a world of vagueness once we start asking concrete questions regarding its realization. This worry is fair enough, but it is not clear that Gould's position passes this same test. Calls for empathy and solidarity are not the stuff of concrete proposals, institutions, or practices.

Wellman-using Norway as a foil for his theoretical exegesis-argues in his chapter that functional state theorists (a broad term for a range of theories that derive state legitimacy from the functions that the state carries out) can muster strong claims for jurisdiction and border controls, but not for the monopolization of resources. It is a tightly argued chapter that also surveys a sub-set of topics in the field. Refreshingly, and like John Tasioulas and Effy Vayena in their chapter, Wellman is eager to clarify and characterize the limitations of rights-based theorization, showing that it is difficult, perhaps impossible, to derive a functional claim for the state's capacity to monopolize resources. This kind of argumentative humility is too rare, and very welcome.

I turn now to more general questions regarding the role of empirical evidence in contemporary global justice theorization. First, what does the Oxford Handbook of Global Justice tell us about the field's engagement with evidence? Unfortunately, the answer is mixed, ranging from poor to excellent.

Consider a few illustrative examples. Gillian Brock's chapter on equal opportunity begins by setting the theoretical stage with an empirical reflection on comparative educational attainment globally. That, it seems to me, is the right approach. However, it is not clear why Brock relies upon seemingly random and, moreover, 40-year-old cases to do so: Mali and the US between 1975 and 1979, as discussed in a 2006 World Bank Development report (p. 36). There is a world of excellent recent literature on this question, and surely that is where we should start.

(c) 2021 The Author(s), under exclusive licence to Springer Nature Limited part of Springer Nature. 1470- S193

8914 Contemporary Political Theory Vol. 20, S4, S192-S197 
Consider another example. To rebut claims that open border policies can reduce harm-a crucial empirical consideration for his argument-Miller states that the poor do not migrate, and that when they do, they likely harm their compatriots left behind. To support this claim, Miller (p. 399) cites a 1997 piece by Pogge (who himself does not cite any sources), and points to more recent theoretical work by Kieren Oberman. These are both odd references. Pogge's data, if it exists, is at least two decades old, and Oberman's article makes the opposite of Miller's point by arguing against immigration restrictions except in rare and extreme cases (Oberman, 2013, p. 427). Indeed, were we to dig deeper, we could also note that Oberman's article is purposefully abstract and premised on the assumption that only one case of deleterious brain drain is needed to justify his theoretical point (Oberman, 2013, p. 429, n. 7). Oberman provides one such example: Zambia losing many doctors and nurses to the UK at the height of the AIDS epidemic (Oberman, 2013 , p. 429). However-and this is a crucial empirical observation for evaluating Miller's theoretical claim-he later notes that 'in some countries, wages for skilled work are insufficient to cover basic needs. The monthly wage of a nurse in Zambia is a mere \$299; this is less than the \$350 a family needs for food' (Oberman, 2013, p. 441). So even in the extreme case picked by Oberman, the consequence of stopping 'brain drain' would only be to keep healthcare professional in place, but not necessarily working (sometimes called 'brain in the drain'). That, it seems to me, is the benefit of attending to evidence when making normative claims: it reveals how norms that appear to augment justice in theory-here, norms defended by Miller-may, if realized in policies, increase injustice in practice.

Similarly, consider Rainer Forst's chapter which sets out a 'critical theory of transnational justice' (p. 451) based on a realistic critique that brings together 'abstract reflections in moral philosophy with sociological empirical realism' (p. 451). Forst develops a compelling philosophical critique; however, the promised line of empirical inquiry is never developed. Instead, the inadequacies of a strict statist or strict cosmopolitan critique are noted (correctly), while a plethora of other sites of justice, injustice, and domination are mentioned as sites where justice concerns should be taken up. Jiwei Ci gets to the heart of the problem with the kind of liberal global justice theory to which Forst also responds. For $\mathrm{Ci}$, ' $[\mathrm{t}]$ here is an almost total absence of self-directed critical causal understanding of global injustice' in Rawls (p. 496). Ci takes Rawls to task for not incorporating an economic critique of capitalism into his political philosophy. This criticism is welcome, but without a substantive account of what $\mathrm{Ci}$ means by capitalism, his critique of Rawls displays the very features he opposes in Rawls' account: it is abstract, dissociated, evocative, and maybe true, but in need of empirical support.

To see why attentiveness to empirics is so important, we need only consider the chapters that engage with empirical evidence. Each quickly reveals that the kind of disengagement sketched above does a disservice to theory. For example, Ronzoni and Valentini show in concrete terms how the spectral leviathan of the state-a

S194 (C) 2021 The Author(s), under exclusive licence to Springer Nature Limited part of Springer Nature. 14708914 Contemporary Political Theory Vol. 20, S4, S192-S197 
spectre that is at the ontological heart of so much of contemporary global justice scholarship_often vanishes with only cursory empirical examination. Valentini and Ronzoni look outward to the powerful supranational institutions that shape much of the international global economic order. They could have also looked inward to (con)federalism, regionalism, cities, provincialism, and inter-governmentalism. This endeavor is part of Cabrera's patient de- and reconstruction of the idea of citizenship at the heart of much liberal global justice theory. Cabrera shows that many of the premises of liberal statist conceptions of citizenship do not support the territorial constraints they are assumed to defend. Cabrera sets out a brief but convincing critique of scholars who have dismissed the idea of global citizenship by both pointing to sheer institutional facts which undermine justifications of national citizenship, while further pointing out that the same arguments mustered to defend national citizenship claims readily support global citizenship claims as well. To give another example of the value of empirical study, Tasioulas and Vayena's chapter on human rights and global health-a masterclass of clear theoretical reasoning, precise argumentation, and attentiveness to empirics-tracks and diagnoses the theoretical and practical limitations of rights discourse in the global health debates. It is a welcome contribution to the debate, both in terms of substance and argumentative style. The best example for the importance of grounded theorization is Ratner's polite but substantively scathing criticism of global justice theorization as seen from the perspective of international law practice. Writing about the lack of mutual engagement between global justice and international law scholars, Ratner shows that global justice theorists are not only unconcerned with the history, practices, norms, puzzles, and problems of actually existing global justice regimes, but their theoretical work is greatly impoverished because of it. For their own part, international jurists of various stripes pay no attention to global justice theory because it serves little to no descriptive, analytical, or normative utility. Ratner outlines the nature of this mutual disregard and considers how to move forward.

Another concern taken up in the volume is the relationship between global justice and environmental devastation. Brooks and Henry Shue both do an admirable job of bringing to bear the empirics of this fundamentally global problem on a series of theoretical questions. Considering looming climate catastrophe, massive inequity, and the pressing normative considerations they pose, Brooks argues for unmooring global justice from Rawls and setting out anew. One cannot help but agree. In the same vein, Shue argues that the very ontological foundations - or phenomenological grounds, in Shue's parlance - of contemporary liberal global justice scholarship may not be able to grapple with the kinds of injustice climate catastrophe portends. These chapters will certainly be of interest to scholars interested in global justice not as a topic in the history of increasingly stale ideas but as a tool for thinking about today's problems. Given that the section

(c) 2021 The Author(s), under exclusive licence to Springer Nature Limited part of Springer Nature. 1470- S195 8914 Contemporary Political Theory Vol. 20, S4, S192-S197 
on climate change promises to be a central issue of scholarship and instruction in years to come, one wishes that it featured more than two chapters.

There are other empirical considerations that are important for thinking about global justice today but are not discussed in this handbook. This is not a criticism of handbook but of the state of the field in general. Take the example of China, which presents two empirical dilemmas for contemporary global justice theorisations. The first is the world-historic reduction of starvation-level poverty in China over the last 50 years. This requires complex analysis, but it is safe to say that none of the institutions and norms exalted by global justice theorists had anything to do with the success of this campaign. Notably, none of the three chapters in the section on severe poverty mention China. The second dilemma is the silence around ongoing mass repression-probably genocide-of Uyghur Muslims in China (however, Anna Stilz mentions the internal colonialism of the Han Chinese in Tibet (p. 441)). Global justice theory has long been criticized for ignoring, or implicitly condoning, genocide, and this handbook is no exception. This is not to say that global justice theorists are able to intervene in political situations, but many of the handbook's stand-out chapters show that there is real payoff in coming to terms with the limitations of an idea. This also applies to relevant problems such as unchecked global corporate power, nuclear proliferation, and global crime cartels (but see Jagger's chapter on the modern sex worker/slave trade), which are all absent from the volume.

In addition to the question about the role of empirical research in global justice theory, a second major question is what the Oxford Handbook of Global Justice tells us about the field's theoretical commitments. The answer seems to be that there are too many missing theoretical critiques (again, this is not a criticism of the handbook, but of the state of the art). In the introduction, Brooks mentions two: just war theory and the philosophy of Albert Camus. Others come to mind: neorepublicanism, libertarianism, post-colonialism, Marxism, and radical democratic theory are all absent or marginal considerations. Likewise, the handbook remains largely Eurocentric. With the exception of Watene's chapter, there is no engagement with African, Asian, South American, Middle-Eastern, and Indigenous theories of global justice.

There are good reasons to think the field would benefit from casting a larger theoretical net. Liberal global justice theory, in particular, would do well to consider non-liberal approaches. Take as an example Stilz's chapter, which examines a problem built into freedom-based arguments for global movement: that they may legitimate settler colonialism. Against this, Stilz argues that because settler colonialism is a form of domination, it should not be considered a legitimate form of free movement. It is a theoretically rich chapter, but it is not obvious that freedom of movement is relevant to understanding the wrongs of settler colonialism. Nevertheless, the core issue is that Stilz gives only fleeting gestures towards what the 'colonized themselves' (p. 435) think are the wrongs of 
colonization. Of course, indigenous scholars and peoples have much to say on these topics, so why not start there? To see why this matters, simply imagine a situation where Stilz's critique of the wrongs of colonization and an indigenous critique differ. Questions abound. That is the negative side of the coin. The positive side would be that they align. That would be remarkable and important validation. Or consider Wellman's case study of Norway, which develops a statist theoretical account without attention to the status of the Sámi people. The Sámi practice what we may call asymmetric jurisdiction, challenge border controls, and assert particular economic powers and privilege against the Norwegian state-all topics in which Wellman is interested. In both examples, the theory would only gain from such an engagement by revealing fundamental problems or strengthening fundamental claims.

One final remark: the editor did a fine job, less so the copyeditors. I found upwards of 150 typos and formatting errors in the handbook. For instance, a whole section of notes is listed twice. Most of the errors are in bibliographies, a few of which seemed to have not been checked even by the authors.

In political theory, few topics are as pressing as global justice. Brooks has done an excellent job surveying the state of the field: a field that, as the handbook illustrates, is partly held back by philosophical and theoretical commitments that are increasingly inapt for the task at hand, a tendency often reinforced and facilitated by a seeming boredom with empirical evidence, and partly propelled by far more promising empirically grounded and theoretically curious approaches to global justice. The future of global justice theory is surely with the latter.

\section{Reference}

Oberman, K. (2013) Can Brain Drain Justify Immigration Restrictions? Ethics 123(3): 427-455.

Publisher's Note Springer Nature remains neutral with regard to jurisdictional claims in published maps and institutional affiliations.

J. Matthew Hoye

Institute of Security and Global Affairs - The Hague, Leiden University, 2300 RA

Leiden, The Netherlands matthewhoye@gmail.com 